\title{
Soil Properties and Crop Yields along the Terraces and Toposequece of Anjeni Watershed, Central Highlands of Ethiopia
}

\author{
Tadele Amare ${ }^{1,3}$, Aemro Terefe $^{2}$, Yihenew G. Selassie ${ }^{2}$, Birru Yitaferu $^{1}$, Bettina Wolfgramm ${ }^{3} \&$ Hans Hurni $^{3}$ \\ ${ }^{1}$ Amhara Regional Agricultural Research Institute (ARARI), Bahir Dar, Ethiopia \\ ${ }^{2}$ Department of Natural Resources Management, College of Agriculture and Environmental Sciences, Bahir Dar \\ University, Bahir Dar, Ethiopia \\ ${ }^{3}$ Center for Development and Environment, Institute of Geography, Department of Integrative Geography, \\ Hallerstrasse 10, CH-3012 Bern, Switzerland \\ Correspondence: Yihenew G. Selassie, Department of Natural Resources Management, College of Agriculture \\ and Environmental Sciences, Bahir Dar University, Bahir Dar, Ethiopia. Tel: 251-918-765-823. E-mail: \\ yihenewgs@gmail.com
}

Received: October 19, 2012 Accepted: November 15, $2012 \quad$ Online Published: January 15, 2013
$\begin{aligned} & \text { doi:10.5539/jas.v5n2p134 } \\ & \text { URL: http://dx.doi.org/10.5539/jas.v5n2p134 }\end{aligned}$

\begin{abstract}
In the Highlands of Ethiopia, soil erosion is a pressing challenge causing deterioration of soil quality including soil fertility. To overcome this problem, the government has been taking various sustainable land management (SLM) measures. This study was conducted in 2011 to investigate the long-term impacts of soil conservation on soil qualities and crop performance at Anjeni watershed in the central highlands of Ethiopia. Soil and crop samples were collected from the lower (deposition), middle and upper (loss) zones of the terraces at a depth of $30 \mathrm{~cm}$. The test crops were maize (Zea mays) and bread wheat (Triticum aestivum). Soil samples were also taken at toe slope, foot slope, back slope, shoulder slope and crest positions of the watershed from $0-30 \mathrm{~cm}$ soil depth to evaluate the status of soil qualities along the catena. Results of the study showed that soil $\mathrm{pH}$, exchangeable cations, available phosphorus, sum of exchangeable bases and percent base saturation showed non-significant difference between the loss zone and deposition zones, whereas higher mean value of organic carbon, and total nitrogen were obtained at the deposition zone than the loss zone. For both testing crops, higher mean yields were found at deposition zones followed by the middle zones while the lowest value was obtained from the loss zones. Soil $\mathrm{pH}$, exchangeable cations, available phosphorus, sum of exchangeable bases, percent base saturation, organic carbon and total nitrogen showed significant variation due to slope position differences. Toe slope position followed by crest slope position showed higher mean value of the parameters. The shoulder slope position had the lowest mean value for all parameters. From the results of the study, it was possible to conclude that soil conservation measures implemented at Anjeni watershed reduced soils erosion, improved soil qualities and increased crop yield. It is, therefore, possible to recommend the need for scaling up of results obtained from learning watersheds on soil conservation activities to the highlands of Ethiopia to improve the soil quality and livelihoods' of the society.
\end{abstract}

Keywords: terraces, toposequence, deposition zones, loss zones, soil properties, crop yield

\section{Introduction}

Natural resources degradation is one of the pressing challenges of Ethiopia. About 1.5 billion metric tons of soil is lost every year from Ethiopia and Eritrea alone (Hurni, 1987). Productivity of the agricultural lands has been reduced as a result of declining of soil fertility. According to Hurni (1993), an annual yield reduction of 1-2\% is estimated due to soil erosion in Ethiopia. The off-site effect of soil erosion has been also higher for water bodies especially lakes and dams. Its negative effect will be more dangerous in the future particularly on irrigation and hydropower infrastructures. On the other hand, irrigation and hydropower developments are among the top priorities given by the country to support its economic growth. The cost of soil erosion in Ethiopia is very high (Bojö, 1996) and will be worse in the future unless the situation is reversed.

Following the extended droughts of Ethiopia in 1973/1974, land degradation has drawn the focus of Ethiopian government (Krüger et al., 1997). Establishment of the stations for Soil Conservation Research Programme (SCRP) in the 1980s with the collaboration of Ethiopian and Swiss Governments was based on Ethiopian's call to the 
international support for SWC technologies. Six SCRP stations were established in the Highlands of Ethiopia. Anjeni watershed is one of the SCRP stations and was established in 1984 to represent the central Highlands of Ethiopia with high annual rainfall and active soil erosion. Natural resources degradation is very high at Anjeni and its surrounding. The average annual soil loss from the test plots without conservation measures was reported to be 90 tonnes and 110 tonnes per hectare on $12 \%$ and $18 \%$ slope gradients, respectively (Herweg \& Ludi, 1999). Gete \& Hurni (2001) also found a declining of natural forest from $27 \%$ in 1957 to $0.3 \%$ in 1995 at Anjeni and its surroundings.

Fanya juи soil conservation measure was introduced to the watershed in 1986 for soil conservation. The construction of the fanya juu was through community mobilization. Since then, the watershed has been used as one of the research sites for soil and water management. Unlike other places, conservation structures are well protected by the communities and soil loss and runoff has been significantly reduced. Moreover, large database on soil loss and runoff has been established that could be used for both research and development. However, the improvement of the soil quality especially the soil organic carbon content as well as the yield of crops due to the structures remained to be untouched research area for the watershed. Therefore, the objective of the research was to quantify the contribution of soil conservation terraces and toposequence on soil quality (soil fertility) and crop yields.

\section{Materials and Methods}

\subsection{Description of the Study Area}

The research was conducted at Anjeni Watershed, Dembecha District, West Gojam Zone of Amhara National Regional State (ANRS), Ethiopia (Figure 1). Its geographical location is $10^{\circ} 40^{\prime} \mathrm{N}$ and $37^{\circ} 31^{\prime} \mathrm{E}$ with an altitude range of 2405-2507 meters above sea level. It has a prolonged and uni- modal rainfall pattern with five months exceeding $100 \mathrm{~mm}$ each (Hurni et al., 2007). The rainy season is between May and October with a mean annual rainfall of about $1690 \mathrm{~mm}$ with a length of growing period of more than 245 days (Hurni et al., 2007). The mean monthly minimum and maximum temperatures range between 6.2 and $26.1^{\circ} \mathrm{C}$ with a lowest recorded temperature of $0^{\circ} \mathrm{C}$ and the highest of $33^{\circ} \mathrm{C}$ (Bosshart, 1997; Gete, 2000; Hurni et al., 2007). The months from November to March show dry conditions with an aridity index of below 20 (SCRP, 2000).

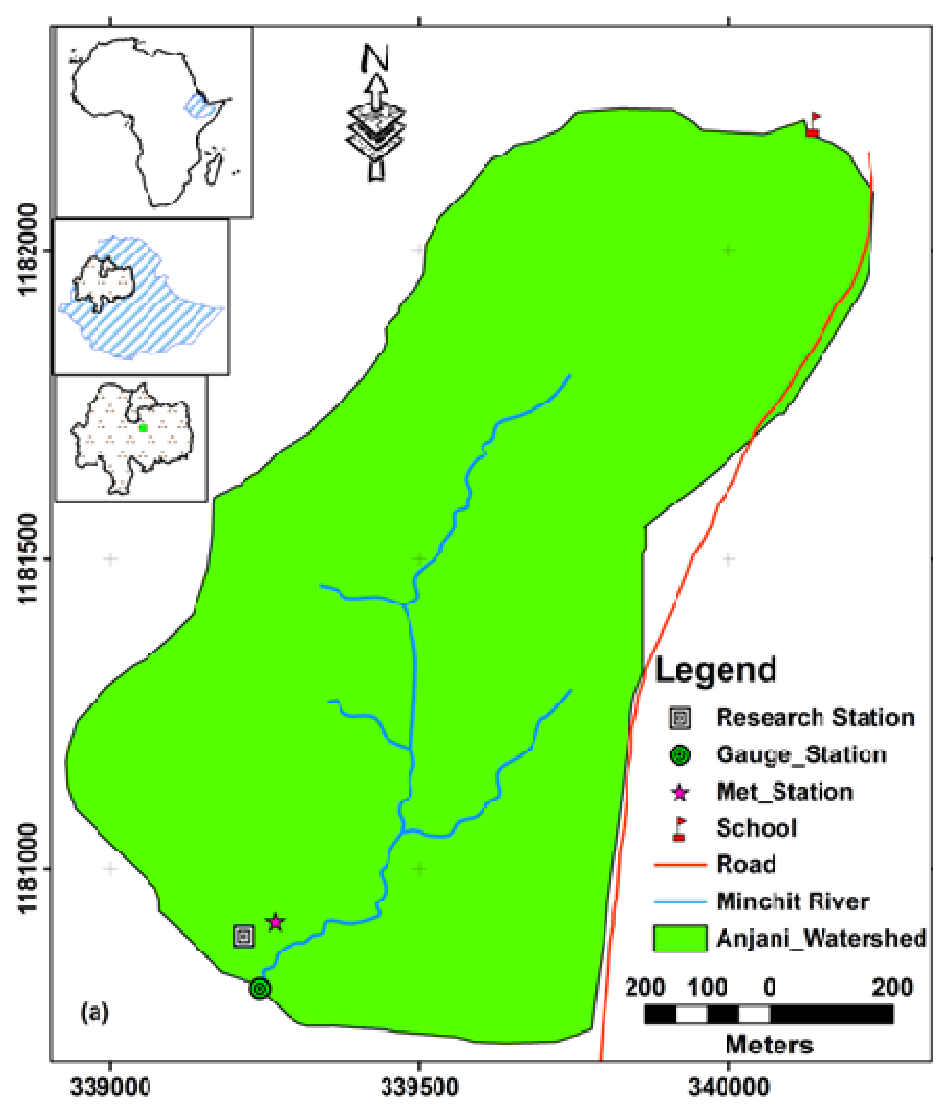

Figure 1. The location of Anjeni watershed in the Blue Nile Basin 


\subsection{Soil and Crop Yield Sampling along the Terrace}

To evaluate the effect of soil terraces on selected soil properties including soil organic carbon, soil samples were collected from both deposition and loss zones of the terraces (Figure 2). Ten terraces that represent the watershed were selected. From each terrace, 2 samples: one from the lower and the other from the upper parts were taken at 2 $\mathrm{m}$ away from each Fanya juu at the depth of 0-30 cm. A total of 20 soil samples were collected. Parallel to each sample, core samples were taken to determine the bulk density of the soil. Core samples were oven dried for 24 hours at $105^{\circ} \mathrm{C}$ then the density of the soil per sample was calculated.

To investigate the effect of terrace on crop performance, bread wheat (Triticum aestivum) and maize (Zea mays L.) were used as test crops. Samples for yield and yield components data were collected using a quadrant of $2 \times 2 \mathrm{~m}^{2}$ for maize and $1 \times 1 \mathrm{~m}^{2}$ for wheat at deposition, middle and loss zones of terraces (Figure 2). For each crop, 36 samples (12 per terrace zone) were taken. The biomass and grain yields were separated and weighed. The moisture content of the grain was measured and adjusted to the standard (12.5\%) moisture content.

Loss zone
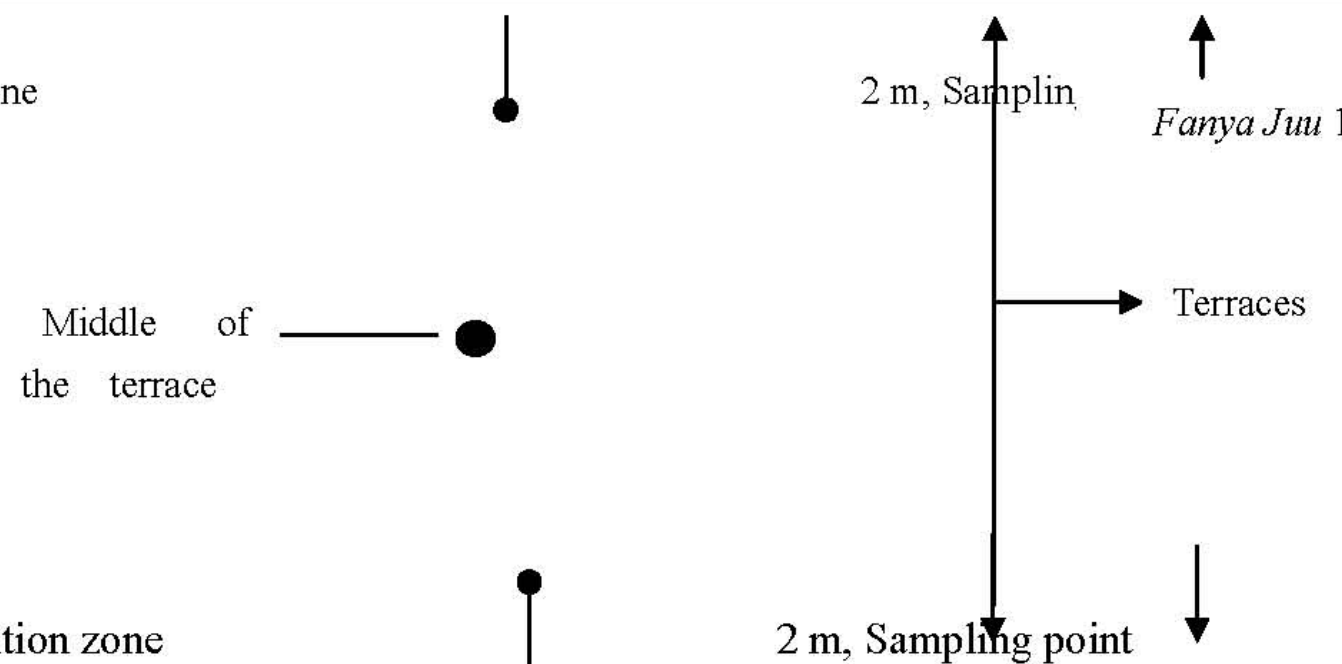

Deposition zone

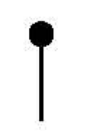

$2 \mathrm{~m}$, Sampling point

Figure 2. Soil and crop sampling points along the terrace

\subsection{Soil Sampling along the Toposequence}

Seven transects perpendicular to the slope were selected. Transects were representing the watershed very well. Soil samples were collected at 0-30 cm depth from top to bottom of each transects. Five samples per transect: at toe slope, foot slope, back slope, shoulder and crest were taken (Figure 3). A total of 35 samples were collected for the analysis of soil attributes. For the terraced landscapes (foot slope, back slope and shoulder slopes), samples were taken at the middle of the terraces while for the non-terraced crest and toe slope landscapes, samples were collected at the maximum and minimum altitudes, respectively for each transect. 


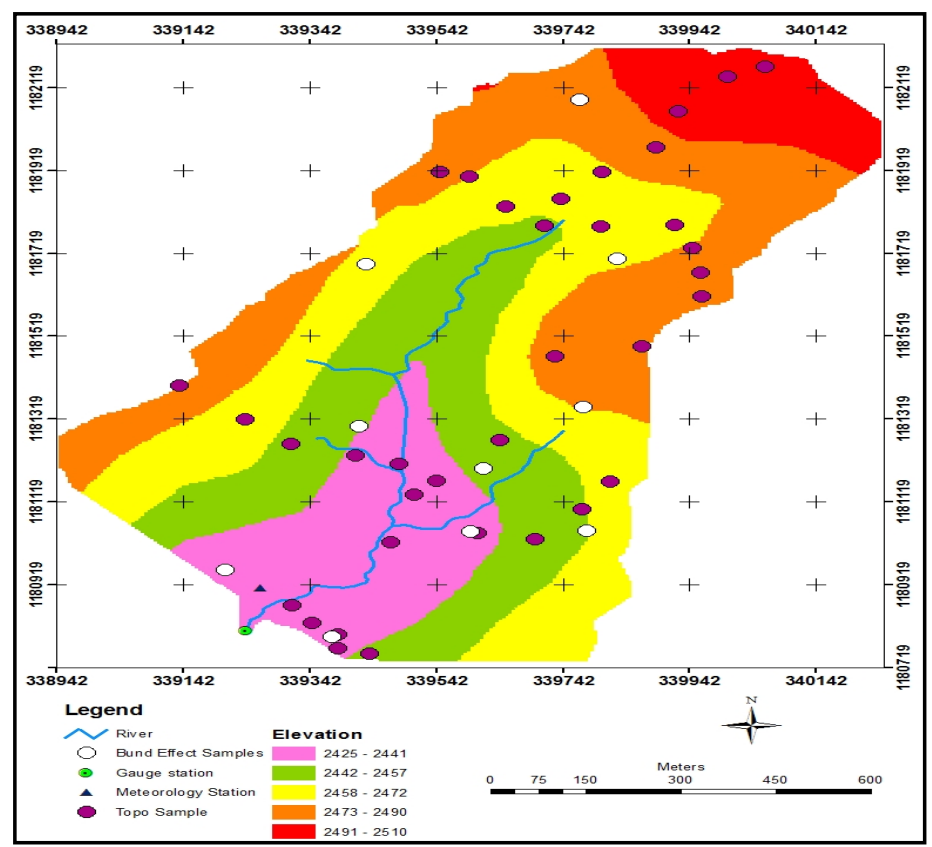

Figure 3. Soil sampling points at the study watershed

\subsection{Soil Analysis}

The samples were air dried under the shade, ground using pestle \& mortar and sieved to pass through $2 \mathrm{~mm}$ sieve. The chemical properties were determined at the National Soil Testing Center, Addis Ababa. Soil pH was determined in a 1:2.5 soil to water suspension following the procedure outlined by Sahlemedihn and Taye (2000). The organic carbon content was analyzed by wet digestion method using the Walkley and Black procedure (Nelson \& Sommers, 1982). Soil organic matter was calculated by multiplying soil organic carbon by a factor of 1.724. The total nitrogen content was determined using the Kjeldahl method (Bremner \& Mulvaney, 1982) while the available phosphorus was determined following the Olsen procedure (Olsen \& Sommer, 1982). The cation exchange capacity (CEC) and exchangeable bases were determined after extraction of the samples with $1 N$ ammonium acetate at $\mathrm{pH} 7$ and the aliquots were measured by atomic absorption for $\mathrm{Ca}^{2+} \& \mathrm{Mg}^{2+}$ and by flame spectrometer for $\mathrm{Na}$ and $\mathrm{K}$ following the procedures described by Sahlemedihn and Taye (2000). The percent base saturation was calculated by dividing the sum of base cations to the cation exchange capacity and multiplied by 100 .

\subsection{Staistical Data Analysis}

The impact of independent variables (terrace and toposequence) on the dependent variables (soil properties and crop yields) was statistically tested. The study was designed to collect equal replications of samples for each independent variable (10 for terraces and 7 for toposequence). Student's t-test was applied for assessing the significant differences between the mean values of soil properties between loss and deposition zones. For data containing more than two factors, analysis of variance (ANOVA) was carried out to determine the presence of significant differences among the treatments using SAS 9.2 software (SAS, 2003). When ANOVA test was found to be statistically significant $(\mathrm{p} \leq 0.05)$, further analysis of mean separation was carried using Duncan's Multiple Range Test (DMRT) at alpha value of 5\%.

\section{Results and Discussions}

\subsection{Effect of Terraces on Soil Properties}

\subsubsection{Soil $\mathrm{pH}$}

The mean value of $\mathrm{pH}$ in water for the loss and depositions zones showed no significant difference ( $\mathrm{p} \leq 0.05)$. This result was in agreement with the finding of Asadi et al. (2010) who found a non-significant difference in soil pH between soils on conserved dry farm land and degraded rangeland of semiarid region of Iran. The soil analysis results (Table 1) showed that the soil $\mathrm{pH}$ for accumulation and loss zones were moderately acidic based on USDA (1998) ratings, which is similar to the report of Alemayehu (2007) for Anjeni watershed. Due to the excessive 
rainfall that causes leaching for basic nutrients (calcium and magnesium), which is the major soil nutrient management problem for the soils of humid tropics. Results of Mulugeta and Stahr (2010) also indicate that tropical soils are deficient in $\mathrm{K}^{+}, \mathrm{Ca}^{2+}$ and $\mathrm{Mg}^{2+}$. Soil $\mathrm{pH}$ could also be associated with the type of parent material and extent of soil erosion. For every half-unit drop in soil $\mathrm{pH}$, percent base saturation declines by about $15 \%$ (Baruah \& Barthakur, 1998). Therefore, the relatively lower $\mathrm{pH}$ mean value for the loss zone could be attributed to the relatively lower base saturation percentage and lower soil organic matter content while the highest $\mathrm{pH}$ value in the accumulation zone could be attributed to the presence of higher exchangeable cations due to reduced erosion.

\subsubsection{Soil Organic Matter (SOM)}

Soil organic matter contents between accumulation and loss zones were highly significantly different $(\mathrm{p} \leq 0.01)$ (Table 1). The variations in mean value of organic matter could be attributed to the erosion reduction effects of soil and water conservation measures implemented and biomass accumulation that agrees with the finding of Million (2003). The same study revealed that soil organic matter content of three terraced sites with original slopes of 15 , 25 and 35\% were higher compared with the corresponding non-terraced sites of similar slopes. This might be due to the washing away of the same from the upper part of terraces and settling down at the lower ones. Siriri et al. (2005) reported that organic carbon decreased down the terrace and higher organic carbon content was found at the upper side of the bund than the lower side. Mulugeta \& Stahr (2010) also found higher soil organic matter (3.69\%) for conserved catchment as compared to non- conserved one (2.24\%).

\subsubsection{Total Nitrogen}

Nitrogen $(\mathrm{N})$ is the most deficient element in the tropics for crop production (Mengel \& Kirkby, 1987). Mesfin (1998) and Yihenew (2007) also reported similar results for Ethiopian soils. The major reasons for this are low organic matter levels in the soil that are caused by the complete removal of biomass and farm yard manure from the field as a feed and source of fire. The difference between the deposition and loss zones for total $\mathrm{N}$ was statistically significant $(\mathrm{p} \leq 0.05)$ and the highest content was found from the deposition zone (Table 1$)$. Alemayehu (2007) also found higher total $\mathrm{N}$ levels on lower parts of the terrace compared to the upper parts of terraces. The total $\mathrm{N}$ content for deposition zone is rated as medium while loss zone of the farm plots rated low according to the rating by Landon (1991). Siriri et al. (2005) also noted lower total $\mathrm{N}$ values on the upper parts of terraces and moderately increased on the lower parts. Million (2003) also found that the total $\mathrm{N}$ content of the terraced site with the slope of 15,25 and $35 \%$ were higher by 26,34 and $14 \%$, respectively compared to their corresponding non-terraced sloping areas.

\subsubsection{Available Phosphorus}

The available phosphorus (P-Olsen) content was higher from the deposition zone than loss zone (Table 1). However, the differences between the loss and deposition zones were not significant. Tadele et al. (2011) \& Vagen (1996) also reported similar results. The variation in available $\mathrm{P}$ between deposition and loss zones can be due to washing out in the upper parts and accumulation at the lower parts. It is apparent that with higher P concentration in the depositions zone there will be relatively higher biomass production and in turn produces higher soil organic matter which is the store of $P$.

\subsubsection{Exchangeable Bases}

Both accumulation and loss zones, irrespective of their soil deposition variation, produced non-significant difference among the mean values of exchangeable $\mathrm{Na}^{+}, \mathrm{K}^{+}, \mathrm{Ca}^{2+}, \mathrm{Mg}^{2+}$, sum of exchangeable bases and percent base saturation (Table 1). The results of this study are in agreement with Tadele et al. (2011) who found a nonsignificant difference in exchangeable bases among different soil and water conservation measures. Zougmore et al. (2002) also found a non-significant difference in mean value for exchangeable $\mathrm{Ca}^{2+}$ after five years of soil conservation by bund in Burkina Faso. But still the concentrations of divalent basic cations were higher in accumulation zone than the loss zone, which could be due to washing away of cations from the loss zone and accumulations in the deposition zone. The mean relative abundance of basic cations in the exchange complex for all the treatments in the study field was in the order of $\mathrm{Ca}^{2+}>\mathrm{Mg}^{2+}>\mathrm{K}^{+}>\mathrm{Na}^{+}$(Table 1) similar to the findings of Yihenew (2002). Contrary to divalent cations, exchangeable $\mathrm{Na}^{+}$content was higher in loss zone than accumulation zone, which may be due to level surface in deposition zone that creates temporary water logging and exposing the monovalent $\mathrm{Na}^{+}$to be easily leached down through the soil profile than other basic cations. Similarly, the SEB was not significant between the loss and deposition zones.

\subsubsection{Cation Exchange Capacity (CEC) and Percent Base Saturation(PBS)}

The mean value of CEC for the treatments in the study area showed statistically significant difference $(\mathrm{p} \leq 0.05)$ (Table 1). This reduction in CEC at the loss zone could be induced by erosion and transportation of clay and 
organic matter at the loss zone. According to Lal et al. (1999), the CEC of a soil can be reduced by soil erosion through the loss of soil organic matter. According to Million (2003), terraced area with original slope of 25 and $35 \%$ had higher mean CEC value than that of the corresponding non-terraced slopes by 6 and $49 \%$, respectively. It is apparent that CEC content positively correlates with organic matter content (Brady \& Weil, 2002) and soil organic carbon (Ruiz-Sinoga, 2012). PBS values were also significantly different $(\mathrm{p} \leq 0.05)$ between the loss and deposition zones.

Table 1. Effect of terraces on selected soil properties

\begin{tabular}{|c|c|c|c|c|c|c|c|c|c|c|c|}
\hline \multirow[t]{2}{*}{ Terrace zone } & \multirow[t]{2}{*}{$\mathrm{pH}$} & \multirow{2}{*}{$\begin{array}{l}\mathrm{OM} \\
(\%)\end{array}$} & \multirow{2}{*}{$\begin{array}{l}\mathrm{TN} \\
(\%)\end{array}$} & \multirow{2}{*}{$\begin{array}{c}\text { Available } \\
\text { phosphorus } \\
\text { (ppm) }\end{array}$} & \multicolumn{5}{|c|}{ Exchangeable bases $^{\dagger}$} & \multirow[t]{2}{*}{$\mathrm{CEC}^{\dagger}$} & \multirow{2}{*}{$\begin{array}{l}\text { PBS } \\
(\%)\end{array}$} \\
\hline & & & & & $\mathrm{Na}$ & $\mathrm{K}$ & $\mathrm{Ca}$ & $\mathrm{Mg}$ & SEB & & \\
\hline Deposition & 5.7 & 3.05 & 0.20 & 7.79 & 0.09 & 1.44 & 8.49 & 2.00 & 12.02 & 21.57 & 58.33 \\
\hline Loss & 6.0 & 1.74 & 0.15 & 6.83 & 0.17 & 1.27 & 8.38 & 2.12 & 11.94 & 20.35 & 55.66 \\
\hline $\begin{array}{l}\text { Student's } \\
\text { t-test }\end{array}$ & $\mathrm{ns}$ & $* *$ & $*$ & $\mathrm{~ns}$ & $\mathrm{~ns}$ & $\mathrm{~ns}$ & ns & ns & $\mathrm{ns}$ & $*$ & $*$ \\
\hline
\end{tabular}

${ }^{* *}$ Significant at $\mathrm{p} \leq 0.01 ; *$ Significant at $\mathrm{p} \leq 0.05 ; \mathrm{ns}=$ non-significant at $\mathrm{p} \leq 0.05$

${ }^{\dagger} \mathrm{Cmol}_{\mathrm{C}} \mathrm{kg}^{-1} ; \mathrm{SEB}=$ Sum of Exchangeable Bases; PBS = Percent Base Saturation

\subsection{Effect of Terraces on the Yield and Yield Components of Wheat and Maize}

The performances of major crops grown at Anjeni were evaluated at loss, middle and deposition zones of the terraces by measuring yield and yield components. There was highly significant differences $(p \leq 0.01)$ among the treatments for all crop parameters for wheat and maize (Table 2). Farmers of Anjeni watershed also noted that the lower parts of the terraces is usually more fertile than the upper one and they use the upper parts for growing a less nutrient demanding crops such as triticale (Triticale hexaploide Lart) while the lower part for relatively higher level of nutrient demanding crops like teff (Eragrostis teff) and wheat (Triticum aestivum) (Figure 4). The accumulation zone was found to have significantly higher $(\mathrm{p} \leq 0.01)$ mean value of grain yield than that of middle and loss zones with mean value of 1077.23, 759.93 and $656.19 \mathrm{~kg} \mathrm{ha}^{-1}$, respectively (Table 2). Enyew and Akalu (2010) also found higher yield from conserved areas that was changed to bench terraces than non-conserved neighboring farmlands. Similarly, Tadele et al. (2011) obtained higher yield from the accumulation zone than loss zone.

The difference between deposition, loss and middle zones of terrace upon the yield and yield components of maize was also statistically significant $(\mathrm{p} \leq 0.01)$. Higher grain yield was recorded at the deposition zone followed by middle and loss zones with grain yield value of $2695.10,1685.90$ and $1072.90 \mathrm{~kg} \mathrm{ha}^{-1}$, respectively. Similarly, the total biomass and plant height showed significant differences between landscape positions (Table 2) at $\mathrm{p} \leq 0.01$.

Table 2. Effect of terrace on the yield and yield components crops*

\begin{tabular}{lcccccc}
\hline Terrace zone & \multicolumn{3}{c}{ Wheat } & \multicolumn{3}{c}{ Maize } \\
\cline { 2 - 7 } & $\begin{array}{c}\text { Grain yield } \\
(\mathrm{kg} / \mathrm{ha})\end{array}$ & $\begin{array}{c}\text { Biomass yield } \\
(\mathrm{kg} / \mathrm{ha})\end{array}$ & $\begin{array}{c}\text { Height } \\
(\mathrm{m})\end{array}$ & $\begin{array}{c}\text { Grain yield } \\
(\mathrm{kg} / \mathrm{ha})\end{array}$ & $\begin{array}{c}\text { Biomass } \\
\text { yield }(\mathrm{kg} / \mathrm{ha})\end{array}$ & $\begin{array}{c}\text { Plant } \\
\text { height }(\mathrm{m})\end{array}$ \\
\hline Deposition & $1077.2^{\mathrm{a}}$ & $5208.3^{\mathrm{a}}$ & $0.64^{\mathrm{a}}$ & $2695.1^{\mathrm{a}}$ & $17125^{\mathrm{a}}$ & $2.38^{\mathrm{a}}$ \\
Middle & $759.9^{\mathrm{b}}$ & $4183.3^{\mathrm{b}}$ & $0.59^{\mathrm{a}}$ & $1685.9^{\mathrm{b}}$ & $10250^{\mathrm{b}}$ & $2.16^{\mathrm{b}}$ \\
Loss & $656.2^{\mathrm{b}}$ & $3491.7^{\mathrm{c}}$ & $0.52^{\mathrm{b}}$ & $1072.9^{\mathrm{c}}$ & $9292^{\mathrm{b}}$ & $2.08^{\mathrm{b}}$ \\
CV (\%) & 22.5 & 12.8 & 10.56 & 36.1 & 21 & 7.48
\end{tabular}

*Values in a column followed by the same letter are not statistically different at $\mathrm{p} \leq 0.05$ 


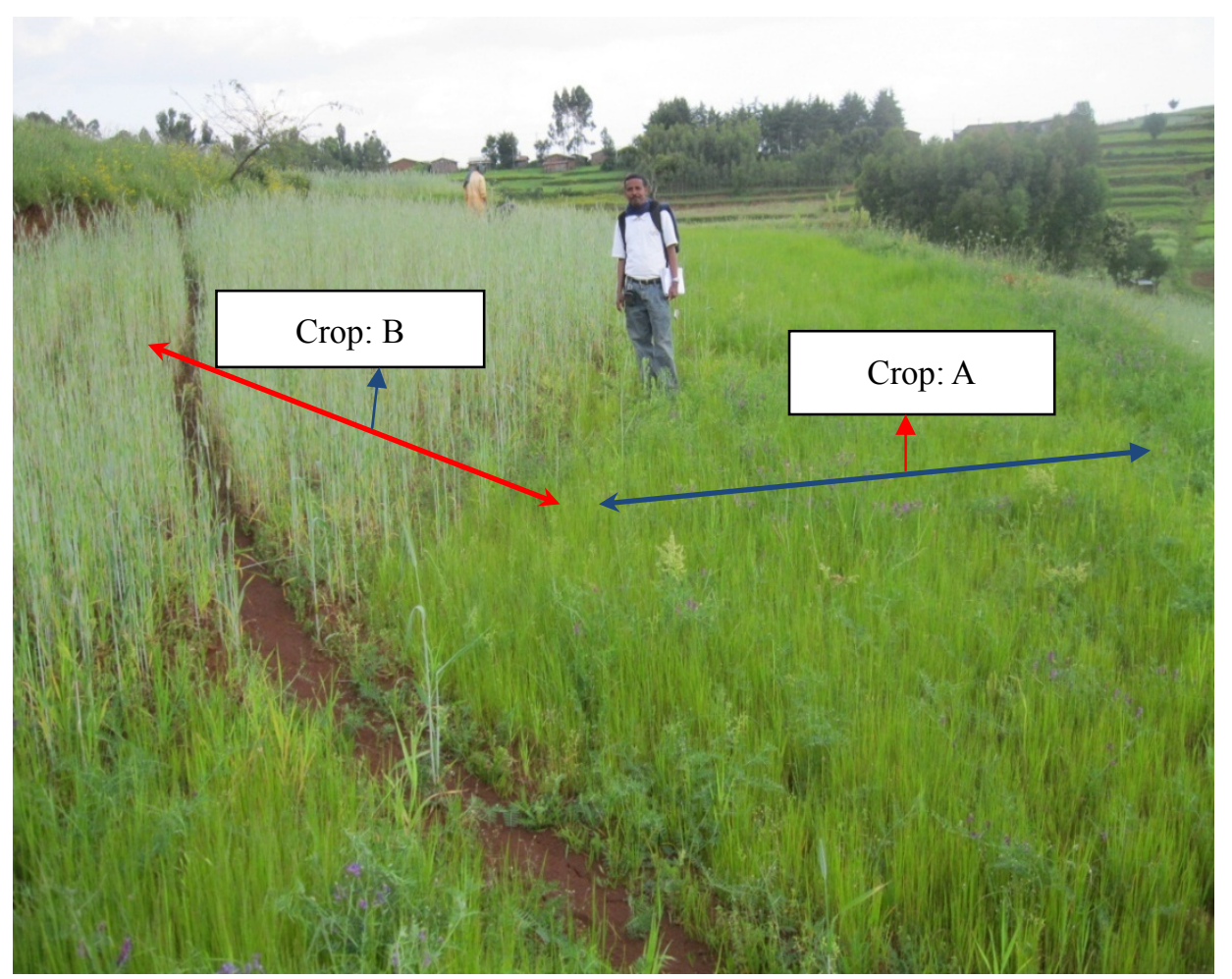

Figure 4. Farmers' practice for the use of low and high fertility soils found at the upper and lower parts of terraces: crop A (teff) and crop B (Triticale), as high and low nutrient demanding crops, are planted at the lower and upper parts of the terraces, respectively (Photo: Tadele Amare, 2010)

\subsection{The Effect of Toposequence on Selected Soil Properties}

\subsubsection{Soil Organic Matter (SOM)}

There was statistically significant $(\mathrm{p} \leq 0.05)$ variation in SOM content among the treatments. As shown in Table 3 , the toe slope had the highest OM followed by crest and foot slopes while shoulder slope has the lowest OM content than the rest of treatments. This may be due to the fact that the toe and crest slopes had relatively more flat slopes in which soil erosion is expected to be negligible as compared to shoulder, back and foot slopes. Because of soil organic matter is highly concentrated at the top layers of soils; it is highly affected by erosion. At the toe slope position higher organic matter content was due to lower erosion rate and higher biomass production at this position. The results of this study were in agreement with that of Bot and Benites (2005); Alemayehu (2007); Moges and Holden (2008); Aweto and Enaruvbe (2010) and Malgwi and Abu (2011). In addition, soils in lower topographic locations are not only characterized by lower slope angles but also hold greater quantity of water than higher slope soil (Lopez et al., 2003; Gao et al., 2009) that slows down the rate of microbial degradation and mineralization of organic matter in toe and crest slope position.

\subsubsection{Total Nitrogen (TN)}

Toe slope had the highest TN than all other positions followed by crest. Statistically, the difference between toe and crest was insignificant while toe slope significantly varied from back slope, shoulder slope and foot slope (Table 3). According to the rating of Landon (1991), the average TN content for toe slope could be rated as medium while the rest are low. Wolde and Veldkamp (2005) also showed that upper slope positions had lower TN than that of middle and foot slopes in the closed areas.

\subsubsection{Available Phosphorus (AP)}

Results presented in Table 3 show that AP content was statically non-significant among treatments. Toe slope had the highest mean AP than all other treatments while crest slope had the lowest mean value. This finding was in agreement with Moges and Holden (2008) as well as Wolde and Veldkamp (2005) who found higher mean value of AP from foot slope position compared to middle slope and upper slope positions. The higher P content in toe slope positions could be associated with higher SOM. 


\subsubsection{Soil pH}

There was a significant difference in mean value of $\mathrm{pH}(\mathrm{p} \leq 0.01)$ among the treatments (positions of the landscapes). The toe slope showed the highest value compared to other positions followed by crest slope. There was no significant variation between foot slope, back slope and shoulder slope as soil erosion is prevalent from these areas (Table 3). The highest $\mathrm{pH}$ value from toe slope and crest slope could be due to high CEC and exchangeable bases. In addition, the slope variations in these treatments were too small. This finding was in line with the findings of Moges and Holden (2008) who found a significant difference in $\mathrm{pH}$ by slope position at both 0 to $15 \mathrm{~cm}$ and 15 to $30 \mathrm{~cm}$ soil depths. On the contrary, Aweto and Enaruvbe (2010) stated that soil pH declines as it goes down slope from upper to lower position partly due to the decline of exchangeable cations (especially magnesium) and base saturation down slope. The effect of erosion was higher than the effect of altitude on the $\mathrm{pH}$ status of Anjeni soil. This could be due to two major reasons: the variation in altitude is smaller between the toe slope and crest slope; while both toe slope and crest positions are relatively flat. The crest part is characterized by lower erosion and lower deposition while the toe slopes with lower erosion and higher deposition. The other positions of the catena have lower deposition and higher erosion. Results of this study agrees with that of Asadi et al. (2010) but contradicts with the reports of Habtamu et al. (2009) who reported that the toe slopes exhibit higher erosion levels.

\subsubsection{Exchangeable Bases}

There was significant variation $(\mathrm{p} \leq 0.05)$ among treatments for exchangeable bases and sum of exchangeable bases (Table 3). Exchangeable $\mathrm{Na}^{+}$content decreased down the slope starting from crest slope to toe slope. Aweto and Enaruvbe (2010) also found highest values of exchangeable $\mathrm{K}$ and $\mathrm{Na}$ on upper slopes while Moges and Holden (2008) found non-significance difference of exchangeable $\mathrm{Na}+$ along a toposequence. According to Lopez et al. (2003), the lower values of sodium at the toe slope accounted for higher nutrient dissolving and leaching capacity of the runoff. Exchangeable $\mathrm{K}^{+}, \mathrm{Ca}^{2+}, \mathrm{Mg}^{2+}$, and SEBs were significantly higher on toe slope than other slope positions, which could be as the result of lower erosion and higher deposition. Following toe slope, crest slope has the highest value in all exchangeable bases and sum of exchangeable bases, which is due to the combined effect of levelness of the land surface and land use variation. Shoulder slope and back slope positions showed the lowest exchangeable cations as it is the site in which most of the cations had been taken by erosion. The results of exchangeable cations were consistent with soil $\mathrm{pH}$ and CEC.

\subsubsection{Cation Exchange Capacity (CEC)}

There was significance variation among different positions for the values of cation exchange capacity (CEC) at $p \leq$ 0.05 . CEC values on the toe and crest slopes were significantly different from those at the shoulder slope. The back slope and foot slope showed non-significant variation from the toe slope, crest slope and shoulder slope (Table 3), with values in the order of toe slope $>$ crest slope $>$ foot slope $>$ back slope $>$ shoulder slope. CEC is one of soil fertility indicators and mainly depends on the organic matter and clay contents of the soil (Rowel, 1994; Wild, 1993). Organic matter content followed the same trend as that of CEC of the soils (Table 3). According to Landon (1991), the top soils having CEC of $>25,15-25,5-15$, and $<5 \mathrm{Cmol}_{\mathrm{C}} \mathrm{kg}^{-1}$ are classified as high, medium, low and very low, respectively. Based on these ratings, all the values in this study can be categorized under medium CEC.

Table 3. Effect of toposequence variation on soil chemical properties*

\begin{tabular}{ccccccccccc}
\hline \multirow{2}{*}{ Position } & \multirow{2}{*}{$\mathrm{OM}(\%)$} & \multirow{2}{*}{$\mathrm{TN}(\%)$} & Available phosphorus $(\mathrm{ppm})$ & $\mathrm{pH}$ & \multicolumn{4}{c}{ Exchangeable bases $^{\top}$} & \multirow{2}{*}{$\mathrm{CEC}^{\dagger}$} \\
\cline { 5 - 8 } & & & & $\mathrm{Na}$ & $\mathrm{K}$ & $\mathrm{Ca}$ & $\mathrm{Mg}$ & \\
\hline Crest & $2.96^{\mathrm{ab}}$ & $0.17^{\mathrm{ab}}$ & $6.90^{\mathrm{a}}$ & $5.9^{\mathrm{b}}$ & $0.45^{\mathrm{a}}$ & $2.06^{\mathrm{ab}}$ & $8.16 \mathrm{a}$ & $2.16^{\mathrm{ab}}$ & $22.64^{\mathrm{a}}$ \\
Shoulder & $1.42^{\mathrm{c}}$ & $0.15^{\mathrm{b}}$ & $7.05^{\mathrm{a}}$ & $5.4^{\mathrm{c}}$ & $0.46^{\mathrm{a}}$ & $1.42^{\mathrm{c}}$ & $7.22 \mathrm{~b}$ & $1.99^{\mathrm{b}}$ & $19.61^{\mathrm{b}}$ \\
Back & $1.99^{\mathrm{bc}}$ & $0.152^{\mathrm{b}}$ & $7.43^{\mathrm{a}}$ & $5.6^{\mathrm{bc}}$ & $0.40^{\mathrm{a}}$ & $1.85^{\mathrm{bc}}$ & $7.42 \mathrm{ab}$ & $2.17^{\mathrm{ab}}$ & $21.12^{\mathrm{ab}}$ \\
Foot & $2.09^{\mathrm{bc}}$ & $0.15^{\mathrm{b}}$ & $7.43^{\mathrm{a}}$ & $5^{\mathrm{c}}$ & $0.42^{\mathrm{ab}}$ & $2.08^{\mathrm{ab}}$ & $7.40^{\mathrm{ab}}$ & $2.03^{\mathrm{ab}}$ & $21.38^{\mathrm{ab}}$ \\
Toe & $3.78^{\mathrm{a}}$ & $0.24^{\mathrm{a}}$ & $8.36^{\mathrm{a}}$ & $6.2^{\mathrm{a}}$ & $0.40^{\mathrm{b}}$ & $2.39^{\mathrm{a}}$ & $8.04^{\mathrm{ab}}$ & $2.49^{\mathrm{a}}$ & $22.88^{\mathrm{a}}$ \\
CV $(\%)$ & 31.37 & 29.97 & 33.63 & 4.2 & 10.57 & 18.08 & 10.49 & 19.72 & 9.77 \\
\hline
\end{tabular}

"Values in a column followed by the same letter are not statistically different at $\mathrm{p} \leq 0.05$.

${ }^{\dagger} \mathrm{Cmol}_{\mathrm{C}} \mathrm{kg}^{-1}$ 


\section{Conclusion}

This study showed that the long-term impacts of soil and water conservation at Anjeni watershed, improved significantly the soil qualities and crop yields. Soil nutrients transported from the upper parts of the terrace are trapped by the conservation structures at the lower sides of the terraces and maintained there; making significant difference between the lower and the upper parts. In high rainfall areas of Ethiopia like Anjeni, nitrogen, and phosphorus and soil organic matter are the main limiting factors for agricultural production. Luckily these soil parameters have been significantly improved within the farm due to terraces, resulting better crop yield performances. Without soil conservation structures, the fate of accumulated nutrients is to be washed away from the farm and transported to other ecosystems; mostly to water bodies which is another cost for the nation. The fertility status of the soil at different landscapes (slopes and altitude) of the watershed showed higher differences, the lower being at the steep slopes which might be associated with old erosion histories (before conservation introduction). The study has great policy implications for the Highlands of Ethiopia about how the soil quality as well as crop yield could be improved and maintained sustainably with proper design and implementation of soil conservation structures. Based on our finding of this research for soil quality and crop yield improvement as well as the long-term data of soil and runoff reduction for Anjeni watershed due to conservation measures, the technology should be promoted to its wider areas of application for the sustainability of the natural resources and improving livelihoods' of the nation.

\section{Acknowledgments}

This paper is based on work conducted within the framework of the Swiss National Centre of Competence in Research (NCCR) North-South: Research Partnerships for Mitigating Syndromes of Global Change. We thank Adet Agricultural Research Center for its facilitation to use soil laboratory facilities. We are also grateful to farmers of Anjeni for their detailed information for the sampling fields and warm communications during our field study.

\section{References}

Alemayehu, A. (2007). Impact of Terrace Development and Management on Soil Properties in Anjeni Area, West Gojam. Master's thesis, Addis Ababa University, Ethiopia.

Asadi, H., Raeisvandi, A., Rabiei, B., \& Ghadiri, H. (2011). Effect of land use and topography on soil properties and agronomic productivity on calcareous soils of a semi-arid region, Iran. Land degradation and Development, 1-9. http://dx.doi.org/10.1002/ldr.1081

Aweto, A. O., \& Iyamah, C. C. (1993). Catenary variation of vegetation in a swamp forest in south western Nigeria. International Journal of Environmental Studies, 43, 133-140. http://dx.doi.org/10.1080/00207239308710820

Baruah, T., \& Barthakur, H. (1998). A Textbook of Soil Analysis. Vikas publishing House Pvt. Ltd., New Delhi, India.

Bojö, J. (1996). Analysis the costs of land degradation in sub-Saharan Africa. Ecological Economics, 16, 161-173. http://dx.doi.org/10.1016/0921-8009(95)00087-9

Bosshart, U. (1997). Catchment Discharge and Suspended Sediment Transport as Indicators of Physical Soil and Water Conservation in the Mayketin Catchment, Afdeyu Research Unit: A Case Study in the Northern Highlands of Eritrea. Soil Conservation Research Programme, Research Report 39. University of Bern, Switzerland.

Bot, A., \& Benites J. (2005). The importance of soil organic matter, key to drought resistant soil and sustained food and production. FAO Soils Bulletin, 80, P78. Rome, Italy.

Brady, N. C., \& Weil R. R. (2002). The nature and properties of soils. Thirteenth edition, Pearson Education, Inc., Upper Saddle River, New Jersy, USA.

Bremner, J. M., \& Mulvaney, C. S. (1982). Nitrogen Total. In A. L. Page, R. H. Miller, D. R. Keeney (Eds.), Methods of Soil Analysis, vol. 2, American Society of Agronomy, Madison, Wis. (1982), 95-624.

Enyew, A., \& Akalu, T. (2010). Effects of long-term soil and water conservation on agricultural productivity: A case study of Anjeni watershed. In Bancy M., ( Ed.), Agricultural Water Management Interventions Bearing Returns on Investment in Eastern and Southern Africa: A compendium of 18 Case studies from six countries in Eastern and Southern Africa, IMAWESA Working Paper 17, 28-39. 
Gao, J. Q., Ouyang, H., Xu, X. L., Zhou, C. P., \& Zhang, F. (2009). Effects of temperature and water saturation on $\mathrm{CO} 2$ production and nitrogen mineralization in alpine wetland soils. Pedosphere, 19(1), $71-77$. http://dx.doi.org/10.1016/S1002-0160(08)60085-5

Gete, Z. (2000). Landscape Dynamics and Soil Erosion Process Modelling in the Northwestern Ethiopian Highlands. PhD dissertation, African Studies Series A16, Bern, Switzerland.

Gete, Z., \& Hurni, H. (2001). Implications of land use and land cover dynamics for mountain resource degradation in the northwestern Ethiopian Highlands. Mountain Research and Development, 21(2), $184-191$. http://dx.doi.org/10.1659/0276-4741 (2001)021[0184:IOLUAL]2.0.CO;2

Habtamu T. Kasahun, Nicholson, C. F., Dawit, S., Collick, A. S., \& Steenhis, T. S. (2009). Economics and policy context for the biological management of soil fertility (BMSF) in Ethiopia. Cornell Soil and Water Lab publication.Retrieved from http://works.bepress.com/chnichol/8

Herweg, K., \& Ludi, E. (1999). The performance of selected soil and water conservation measures, case studies from Ethiopia and Eritrea. Catena, 36, 99-114. http://dx.doi.org/10.1016/S0341-8162(99)00004-1

Hurni H. (1993). Land degradation, famine, and land resource scenarios in Ethiopia. In: World Soil Erosion and Conservation. D. Pimentel (eds.). Cambridge Studies in Applied Ecology and Resource Management, $27-61$.

Hurni, H. (1987). Erosion - productivity- conservation systems in Ethiopia. In I. Plasentis (Ed.), Soil Conservation and Productivity (pp. 654-674). Proc. of the 4th Int. Soil Conservation Conference, Maracay, Venezuela.

Hurni, H., Amare, B., Herweg, K., Portner, B., \& Veit, H. (eds.). (2007). Landscape Transformation and Sustainable Development in Ethiopia. Background information for a study tour through Ethiopia, 4-20 September 2006, compiled by the participants. Centre for Development and Environment, University of Bern, Switzerland.

Lal, R, Mokma, D., \& Lowery, B. (1999). Relation between Soil Quality and Erosion. In R. Lal (Ed.), Soil and Water Conservation Society of America, 237-258.

Landon, J. R. (1991). Booker tropical Soil Manual: A Handbook for Soil Survey and Agricultural Land Evaluation in the Tropics and Subtropics. Longman Scientific and Technical, Essex, New York.

Lopez, I. F., Lambert, M. G., Mackay, A. D., \& Valentine, I. (2003). The influence of topography and pasture management on soil characteristics and herbage accumulation in a hill pasture in the north Island of New Zealand. Plant and Soil, 255, 421-434. http://dx.doi.org/10.1023/A:1026062502566

Krüger, H. J., Berhanu, F., Yohannes, G., \& Kefeni, K. (1997). Inventory of indigenous soil and water conservation measures on selected sites in the Ethiopian Highlands. Soil Conservation Research Programme Research Report 34, Centre for Development and Environment, University of Bern Switzerland.

Malgwi, W. B., \& Abu, S. T. (2011). Variation in some physical properties of soils formed on a hilly terrain under different landuse types in Nigerian Savanna. International Journal of soil sciences, 6(3), 150-163. http://dx.doi.org/10.3923/ijss.2011.150.163

Mengele, K., \& Kirby, E. A. (1987). Principles of Plant Nutrition. Panima Publ. Corporation, New Delhi, India.

Mesfin, A. (1998). Nature and Management of Ethiopian Soils. Alemaya University of Agriculture, Ethiopia.

Million, A. (2003). Characterization of Indigenous Stone Bunding (Kab) and Its Effect on Crop Yield and Soil Productivity at Mesobit-Gedba, North Showa Zone of Amhara Region. Master's thesis, Alemaya University, Ethiopia.

Moges, A., \& Holden, N. M. (2008). Soil fertility in relation to slope position and agricultural land use: A case study of Umbulo catchment in southern Ethiopia. Environmental Management, 42, 753-763.

Mulugeta, D., \& Stahr, K. (2010). Assessment of integrated soil and water conservation measures on key soil properties in south Gondar, north-western Highlands of Ethiopia. Journal of Soil Science and Environmental Management 1(7), 164-176. http://dx.doi.org/10.1007/s00267-008-9157-8

Nelson, D. W., \& Sommers, L. E. (1982). Total carbon, Organic Carbon and Organic Matter. In A. L. Page (Ed.), Methods of Soil Analysis. Part 2: Chemical and Microbiological Properties (pp. 539-579), Agron. 9. Madison, Wisconsin.

Olsen, S. R., \& Sommers, L. E. (1982). Phosphorus. In A. L. Page (Ed.), Method of Soil Analysis (pp. 403-430). Part 2: Chemical and Microbiological Properties. Agronomy 9. Madison, Wisconsin.

Rowel, D. L. (1994). Soil Science Methods and Applications. Longman, London. 
Ruiz-Sinoga, J. D., Pariente S., Diaz, A. R., \& Martinez-Murillo, J. F. (2012). Variability of relationships between soil organic.

Carbon and some soil properties in Mediterranean rangelands under different climatic conditions (South of Spain). Catena, 94, 17-25.

Sahlemedihn, S., \&Taye, B. (2000). Procedures for Soil and Plant Analysis. Technical paper no. 74. National Soil Research Centre, Ethiopian Agricultural Research Organization, Addis Ababa, Ethiopia.

Statistical Analysis System (SAS). (2003). SAS Institute Inc., Statistical Analysis System, Cary, NC, USA.

SCRP (Soil Conservation Research Programme). (2000). Area of Anjeni, Gojam, Ethiopia: Long-term Monitoring of the Agricultural Environment 1984-1994. Soil Erosion and Conservation Database, Soil Conservation Research Programme. Centre for Development and Environment, University of Bern, Switzerland.

Sirri, D., Tanya, M. M, Rousse, T., \& Sake, J. K. (2005). Crop and soil variability on terraces in the Highlands of SW Uganda. Land Degradation and Development, 16, 569-579. http://dx.doi.org/10.1002/ldr.688

Tadele, A., Yihenew, G.S., Mitku, H., \& Yamoh, C. (2011). Effect of soil and water conservation measures on selected soil physical and chemical properties and barley (Hordeum spp.) yield. Journal of Environmental Science and Engineering, 11, 1483-1495.

USDA. (1998). Conservation Service, Soil Information Sheet, Soil quality Indicators: pH. Natural Resources. Retrieved from http://soils.usda.gov/sqi/publications/files/indicate.pdf

Vagen, T. G. (1996). Phosphorus Status in Soils from Terraced and UN- terraced Land on Highly Eroded Slopes in Tigray, Ethiopia. Master's thesis, Agricultural University of Norway, Norway.

Wild, A. (1993). Soils and the Environment: An introduction. Cambridge, UK: Cambridge University Press.

Wolde, M., \& Veldkamp, E. (2005). Impacts of landuse changes on soil nutrients and erosion in Tigray, Ethiopia, Conference on International Agricultural Research for Development, Deutscher Tropentag 2005, Stuttgart-Hohenheim, October 11-13, 2005.

Yihenew, G. (2002). Selected chemical and physical characteristics of soils of Adet Research Centre and its testing sites in north western Ethiopia. Ethiopian Journal of Natural Resources, 4(2), 199-215.

Yihenew, G. (2007). Evaluation of Nitrogen and Phosphorus as Yield-Limiting Nutrients for Maize Grown on

Alfisols of Western Amhara. Ethiopian Journal of Natural Resources, 9(1), 155-170.

Zougmore, R. Z., Gnankambary, S., \& Stroosnijedr, L. G. (2002). Effects of stone lines on chemical characteristics, under continuous cropping in semiarid Burkina Faso. Soil and Tillage Research, 66, 47-53. http://dx.doi.org/10.1016/S0167-1987(02)00012-0 